\title{
Coffee production and marketing in the municipality of Cuetzalan del Progreso, Puebla, Mexico
}

\section{Producción y comercialización de café en el municipio de Cuetzalan del Progreso Puebla, México}

XIMITL-ISLAS, Iván*广, RODRÍGUEZ-DE LA VEGA, Marisol, CABILDO-OREA, Alejandra and MACHORRO-DÍAZ, Rafael

Universidad Tecnológica de Tecamachalco, Avenida Universidad N 1, Colonia La Villita, C.P. 75483.

ID $1^{\text {st }}$ Author: Iván, Ximitl-Islas / ORC ID: 0000-0002-6525-5106, Researcher ID Thomson: S-7952-2018, CVU CONACYT ID: 168266

ID $1^{\text {st }}$ Co-author: Marisol, Rodríguez-De La Vega / ORC ID: 0000-0002-0263-4504, Researcher ID Thomson: S-77742018, CVU CONACYT ID: 424632

ID $2^{\text {nd }}$ Co-author: Alejandra, Cabildo-Orea / ORC ID: 0000-0002-6088-5707, Researcher ID Thomson: S-7798-2018, CVU CONACYT ID: 947359

ID $3^{\text {rd }}$ Co-author: Rafael, Machorro-Díaz / ORC ID: 0000-0002-1776-7174, Researcher ID Thomson: S-7910-2018, CVU CONACYT ID: 947608

DOI: $10.35429 / J I E C .2020 .7 .4 .7 .18$

Received July 15, 2020; Accepted December 30, 2020

\section{Abstract}

It is a privilege to present a regional study on coffee growing in the Northeastern Mountains of Puebla. It has been a historical region where the cultivation of aromatic coffee was introduced due to its geographical and cultural characteristics. The ethnic groups that predominate are Nahwatl and Totonac, who have combined the cultivation of coffee with other basic crops. Coffee has been a perennial and shade crop, that has been adapted to the regional climatic conditions. In Mexico the 5 main States with the largest coffee production are: Chiapas, Veracruz, Oaxaca, Puebla and Guerrero. The State of Puebla has a significant quantity of production at a national and international level. The price of coffee is quoted internationally on the stock exchanges in the Futures Markets of the New York and London Stock Exchanges where brokers operate in financial transactions, in view of this situation it is important to analyze the relationships established between international financial markets prices and how the national, regional and local price is derived, as well as the determination of the living conditions of indigenous producers in the municipality of Cuetzalan del Progreso, Puebla.

Broker, Coffee growing, Coffee prices, Peasant organization

\section{Resumen}

En esta ocasión tenemos la oportunidad de presentar un estudio regional sobre la cafeticultura en la región de la Sierra Nororiental de Puebla, siendo una región histórica donde se introdujo el cultivo del aromático por sus características geográficas y culturales. Los grupos étnicos que predominan son Nahuas y Totonacos, que han combinado el cultivo del café con cultivos básicos, el café siendo un cultivo perenne y de sombra, en el cuál se ha adaptado a las condiciones climáticas de la región, en México los 5 estados con la mayor producción de café son: Chiapas, Veracruz, Oaxaca, Puebla y Guerrero, el Estado de Puebla es uno de los principales productores de café aportando una cantidad de producción a nivel nacional e internacional. El precio de café se cotiza a nivel internacional en las bolsas de valores en los Mercados de Futuros de las Bolsas de New York y Londres donde operan los brókers en las transacciones financieras, ante esta situación es importante analizar las relaciones que se establecen entre los mercados financieros internacionales y como se deriva el precio nacional, regional y local, así como la determinación de las condiciones de vida de los productores del municipio de Cuetzalan del Progreso en Puebla.

Bróker, Cafeticultura, Cotización, Organización campesina

Citation: XIMITL-ISLAS, Iván, RODRÍGUEZ-DE LA VEGA, Marisol, CABILDO-OREA, Alejandra and MACHORRODÍAZ, Rafael. Coffee production and marketing in the municipality of Cuetzalan del Progreso, Puebla, Mexico. RINOE Journal - International Economy. 2020. 4-7:7-18.

\footnotetext{
* Correspondence to Author (Email: ivanximitl@ @otmail.com)

$\dagger$ Researcher contributing first author.
} 


\section{Introduction}

Coffee cultivation is mainly found in 12 states of the Mexican Republic, grouped into four large regions that go from the southern border that borders Guatemala, to the state of Nayarit, in the North Pacific, each region shows its own characteristics, but in most of them with adequate conditions for the generation of quality coffee.

A) Spring of the Gulf of Mexico: Includes the states of San Luis Potosí, Querétaro, Hidalgo Puebla and Veracruz, part of Oaxaca and Tabasco, B). Pacific Ocean slope: This is where the states of Colima, Guerrero, Jalisco and part of Oaxaca, C) are located. Soconusco Region: It is made up of a large part of the state of Chiapas, this region produces a significant volume of organic coffees. Demanded by the US and European markets, D). North-central Chiapas region: It has periods of drought from November to April due to the humid winds from the Gulf of Mexico.

The objective of this research was a regional investigation in which the relationship and the impact of the international price of coffee is analyzed, in the municipality of Cuetzalan del Progreso, Puebla. Based on the analysis of coffee prices that are listed on the New York and London stock exchanges, in the prices: Composite, Brazilian, Colombian, Robustas (Vietnam) and Other Arabicas (Mexican coffee) with data from the International Organization of the Coffee (ICO), the linear regression in time series will be calculated from 1990 to 2019, the study will be complemented with a field study with coffee producers to analyze the impact of the international price with the local price. The fall in international coffee prices and the high costs of production in inputs, labor force, cultural activities have directly affected the living conditions of coffee producers. Peasant organizations are an alternative to give added value to coffee and thereby improve the family income of the members. Faced with the recurring crises in international coffee prices and the inadequate participation of public policies implemented in the coffee sector, producers and peasant organizations present as an alternative to reduce intermediaries and give added value to coffee in the production chain, obtaining benefits in the participants.

\section{International coffee prices}

In the Report of the International Coffee Organization

http://www.ico.org/documents/cy2020-21/cmr1020 -c.pdf the analyzes of the main groups of International Prices are presented, 5 groups being: Brazilian, Colombian, Robustas, Other Arabica and the Composite, these price indicators in cents per pound. (See graphs 1, 2,3,4 and 5).

Coffee exports increased in September 2020, but those for the whole of 2019/20 decreased by $4.9 \%$ The ICO composite indicator price decreased in October by $8.9 \%$, to 105.85 US cents per pound, since the indicative prices of all groups fell, although the greatest decrease was that of Brazil and Other Naturals. In September, world exports increased $0.9 \%$ to 10.16 million bags, as the increase in Robusta exports offset the decrease in those of Arabica. Exports in coffee year 2019/20 decreased by $4.9 \%$, to 126.9 million bags, and the value of these exports, compared to coffee year 2018/19, fell by $3.6 \%$, to 17.87 billion dollars. It is estimated that world coffee production in 2019/20 was 168.84 million bags, $2.5 \%$ lower than the previous year, and that world coffee consumption fell $0.9 \%$, to 167,59 million bags, resulting in a surplus of 1.24 million bags (ICO, 2020).

World production in 2019/20 is estimated to be 168.84 million bags, $2.5 \%$ lower than in 2018/19. Production of Arabica is estimated to have decreased $5 \%$ to 96.05 million bags and Robusta production increased $1.1 \%$ to 72.78 million bags. The drop in production is mainly attributed to the reduction of that of Brazil because it was the low crop year of its Arabica production cycle. Current low prices and the effects of COVID19 on labor availability also contributed to the decline in production. (ICO, 2020).

In coffee year 2019/20, world coffee exports fell $4.9 \%$ to 126.9 million bags, compared to coffee year 2018/19. Between October 2019 and September 2020 there was the smallest decline in Robusta exports, of $1.4 \%$, to 48.68 million bags. 
Exports of Other Milds increased by $9.8 \%$, to 25.15 million bags, those of Colombian Milds by $7.2 \%$, to 13.88 million bags, and those of Brazil and Other Naturals by $4.9 \%$, to 39.18 million bags. The total value of coffee exports decreased by $3.6 \%$ to US $\$ 17.87$ billion compared to coffee year 2018/19, while the average unit value per pound of green bean equivalent decreased at 148.66 cents compared to 177.50 cents in 2018/19. (ICO, 2020).

In 2019/20, green Robusta exports fell $1.6 \%$ to 42.65 million bags, largely due to the decline in Viet Nam's exports, which accounted for $56 \%$ of all green Robusta exports. Viet Nam's exports fell $8.6 \%$ to 24.05 million bags. However, green Robusta exports from Brazil increased $21.2 \%$ to 4.63 million bags, Uganda's $25.9 \%$ to 4.39 million, and Indonesia's $31 \%$ to 3.93 million bags. In contrast, green Robusta exports from India fell $14.3 \%$ to 2.78 million bags. The total value of green Robusta exports decreased $8 \%$, to $\$ 3.93$ billion, compared to \$ 4.27 billion in $2018 / 19$ and $\$ 4.77$ billion in $2017 / 18$. The average unit value decreased by $6.5 \%$, to 69.6 cents, (ICO, 2020).

Roasted coffee exports increased each year in a row, from 370,000 bags in $2014 / 15$ to 788,000 in 2018/19. However, in 2019/20, roasted coffee exports fell $15 \%$, to 669,000 bags. Colombia is the largest exporter of roasted coffee and that country's exports grew $15 \%$, to 198,000 bags. Those of Mexico, on the other hand, fell by $12.7 \%$, to 194,000 bags.

The volume of those from Indonesia more than doubled, to 48,500 bags, while that of Brazil fell $11.2 \%$ to 23,000 bags. Although the volume of roasted coffee exports decreased in $2019 / 20$, the total value increased by $7.8 \%$ to $\$$ 176.36 million.

Additionally, the average unit value of roasted coffee increased $26.8 \%$ to 199.18 US cents per pound. (ICO, 2020). The integrated information on international coffee prices is grouped in figure 6 , to have a relationship of prices in time series.

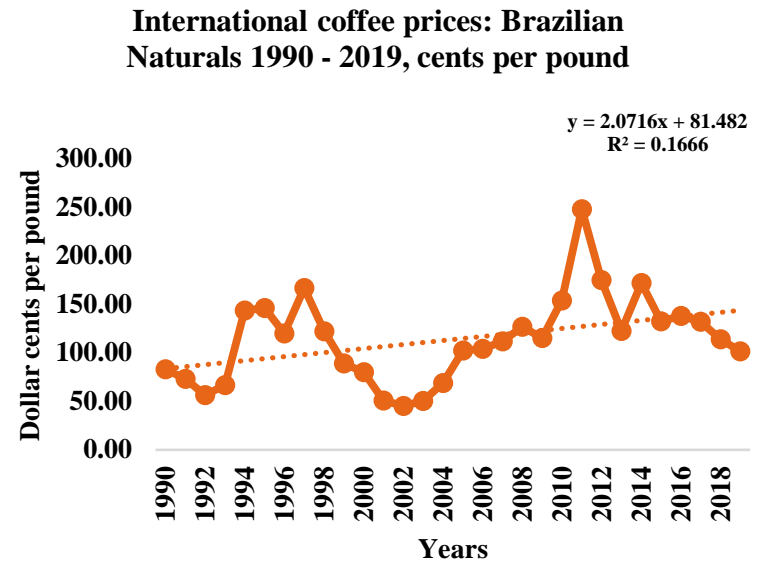

Figure 1

Source: Own elaboration with data from (C) International Coffee Organization www.ico.org, http://www.ico.org/es/new_historical_c.asp consulted: February 05, 2020

International coffee prices: Colombian Milds 1990 - 2019, US cents per pound

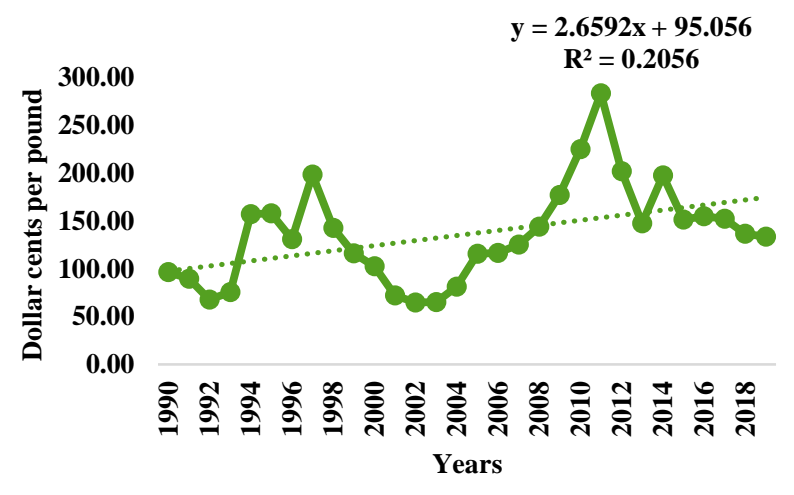

Figure 2

Source: Own elaboration with data from (C) International Coffee Organization www.ico.org, http://www.ico.org/es/new_historical_c.asp consulted: February 05, 2020

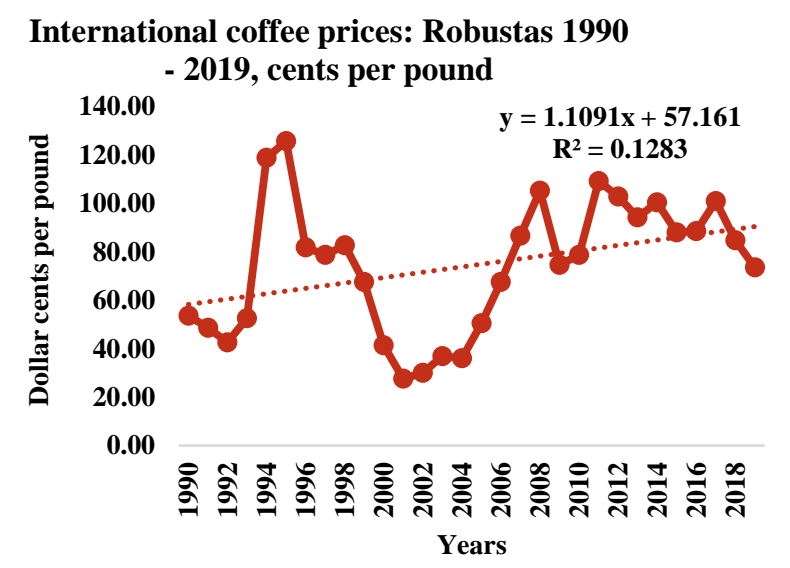

Figure 3

Source: Own elaboration with data from $($ International Coffee Organization www.ico.org, http://www.ico.org/es/new_historical_c.asp consulted: February 05, 2020 


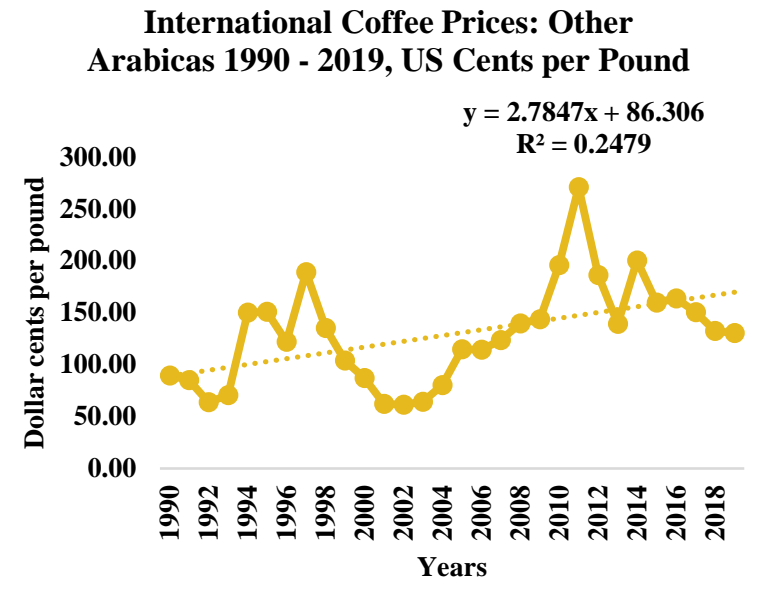

Figure 4

Source: Own elaboration with data from $\odot$ International Coffee Organization www.ico.org, http://www.ico.org/es/new_historical_c.asp consulted: February 05, 2020

International Coffee Prices: Composite Indicative 1990 - 2019, US cents per pound

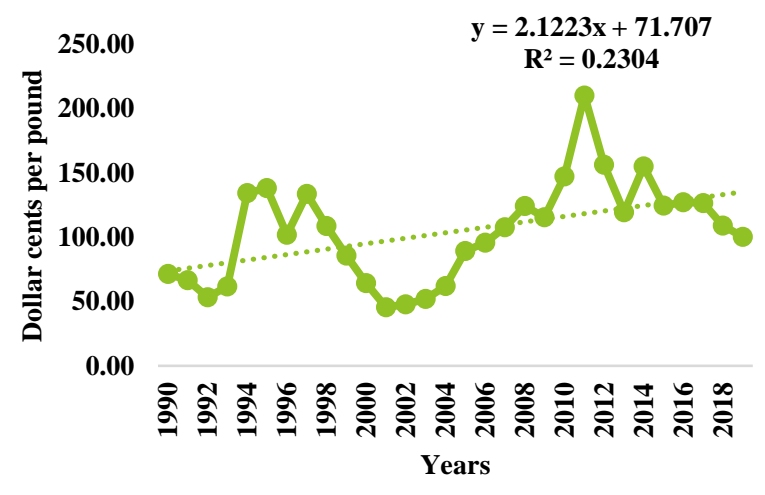

Figure 5

Source: Own elaboration with data from ( International Coffee Organization www.ico.org, http://www.ico.org/es/new_historical_c.asp consulted: February 05, 2020

International coffee prices 1990 - 2019, cents per pound

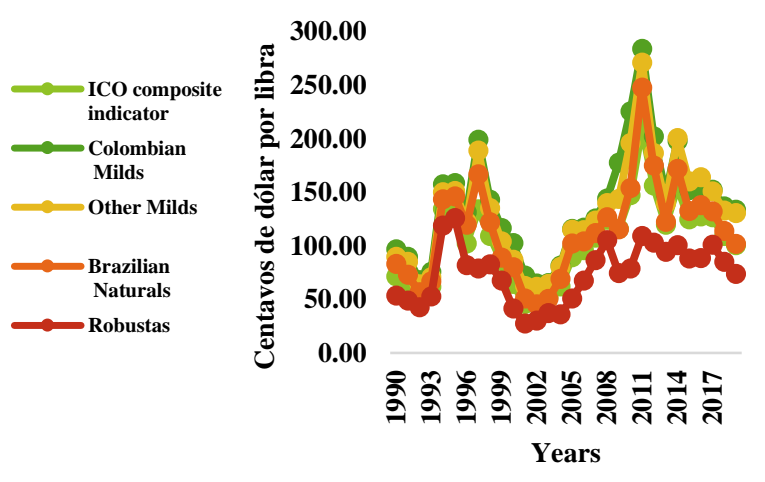

Figure 6

Source: Own elaboration with data from ( International Coffee Organization www.ico.org, http://www.ico.org/es/new_historical_c.asp consulted: February 05, 2020

\section{Methodology}

The information collected was classified into primary and secondary, the first concerns obtaining information through questionnaires, interview cards, research guides, ordinary observation, the second refers to that which is extracted from documentary sources, censuses, vital statistics, through statistical tables, the secondary information serves as the basis for the analysis of the problem, in the information collection, producers and leaders of organizations in the region were interviewed who provided first-hand information on the different aspects of the study.

The field work will be carried out through a random sample of producers with which inference can be made from the results obtained in the survey applied to the target population.

\section{Technique and instrument used}

The technique be it the survey, structured interview, or observation has its own limitations in research. The survey was the technique used to explore certain aspects of the population, it was also required to use observation and interviewing key informants. Regarding the experience in economics studies, the selected technique was the survey, this technique consists of the compilation of a part of the population called sample, data, opinions, through questions formulated on various indicators, the information obtained is processed in a quantitative analysis, in order to identify and know the magnitude of the problem, the instrument used was the questionnaire. In such a way that the elaboration of the questionnaire was directed towards representatives of organizations and producers, where the questions formulated were directed to know the specific aspects of the variables, the exploration of them can be with one or more questions and sometimes a single question served to investigate one or more variables. 


\section{Gathering information from secondary sources}

The first phase consisted of the collection of bibliographic information regarding the research problem in books, newspapers, theses and magazines, in the libraries of the B.U.A.P., the Postgraduate College and newspaper libraries. Subsequently, secondary or statistical information was collected in I.N.E.GI. (Censuses, Yearbooks and municipal notebooks) in the city of Puebla, as well as the consultation via Internet of the official pages of I.N.E.G.I., SADER, O.I.C (Organización Internacional del Café), C.M.C. (Consejo Mexicano del Café) C.P.C. (Poblano Coffee Council), for this stage the bibliographic synthesis method was used, using the instrument called bibliographic worksheet, with the information obtained a database will be made to interpret the situation of coffee production at the national level, state and municipal.

\section{Record of information captured by direct observation}

In the second phase, outings were made to the study municipalities, in order to have contact with key informants: municipal authorities, representatives of peasant organizations, intermediaries and producers. The purpose of this activity was to identify the regional marketing channels, as well as to identify the main points of sale, in roasters within and outside the State of Puebla, in turn, to know where these wholesale and retail organizations make the product.

\section{Registration of direct information from primary sources}

The third phase will consist of the elaboration of questionnaires to apply them in the organizations in the study municipalities, the interviews will be carried out in the second half of July and the first of August, applied first in the municipality of Huehuetla, to conclude in Cuetzalan del Progreso.

\footnotetext{
1 Benito Ramírez Valverde (2003) Project "Study on strategies for the Sustainable Development of the Sierra Nor-oriente de Puebla with the participation of producers, organizations and institutions as a response to the conditions of poverty and marginalization" First semi-annual report. Mixed Fund for Scientific and Technological Research CONACYT - Government of the State of Puebla. Puebla Mexico Pp - 3.
}

The technique of interviewing the two council presidents of the two study organizations was used, using a field notebook and questionnaire guide. This interview technique is used to capture information about the problems and perspectives of the groups for the coffee marketing process.

\section{Information coding and processing}

The next phase was the emptying of the information obtained in the questionnaires in tabular sheets, to create a database by code, later the data was analyzed in the Statstical Pachage for the Social Sciences (S.P.S.S.) program.

\section{The sample design}

The information obtained from the Poblano Coffee Council became the sample design. It was possible to identify that there are 54,725 estates dedicated to coffee cultivation in the State of Puebla. These lands are located in 5 of the eight Rural Development Districts that make up the state. The importance of cultivation in each of the districts is different and it was found that the most important are those of Teziutlán and Huahuchinango, with more than $80 \%$ of the properties. According to this information, most of the coffee producers are located in the Sierra Norte de Puebla. It is in this area where we focus our research and it basically includes 16 municipalities, where the vast majority of the inhabitants are indigenous (Totonacos and Nahuas), in conditions of very high marginalization. ${ }^{1}$

\begin{tabular}{|l|r|r|}
\hline \multicolumn{1}{|c}{$\begin{array}{c}\text { Rural Development } \\
\text { District }\end{array}$} & Frequency & Percentage \\
\hline Huahuchinango & 19782 & 36.1 \\
\hline Libres & 909 & 1.7 \\
\hline Tehuacan & 5865 & 10.7 \\
\hline Teziutlán & 25109 & 45.9 \\
\hline Zacatlán & 3058 & 5.6 \\
\hline Total & 54725 & 100 \\
\hline
\end{tabular}

Table 1 Number of farms planted with coffee by D.D.R. in the state of Puebla

Source: Cited by Ramírez 2003, CONACYT Research Project - Government of the State of Puebla
XIMITL-ISLAS, Iván, RODRÍGUEZ-DE LA VEGA, Marisol, CABILDO-OREA, Alejandra and MACHORRO-DÍAZ, Rafael. Coffee production and marketing in the municipality of Cuetzalan del Progreso, Puebla, Mexico. RINOE Journal International Economy. 2020 
Information on coffee growers in this region was sought and the list of problems was obtained through the coffee census, this census includes information that will allow us to determine the necessary sample size, the first thing that was done was to identify a variable that gives us related information with the research topic and it was dedicated to use the number of farms as a necessary variable to determine the sample size in the first stage was to identify the total number of farms that were located in the two municipalities studied, in the calculation of the average and the variance, as well as other important measures of each of the municipalities contemplated in the study.

\section{Producer Sample Size}

When analyzing the information, it was determined that the adequate sampling scheme for these data was a random stratified sampling, and due to the differences in the population sizes of each stratum, it was decided to assign proportionally to each of the municipalities.

The equation to estimate the sample size in a random stratified sampling with proportional distribution, and is explained as follows:

Equation 1. Mathematical expression to calculate the sample size in a random stratified with proportional distribution

$$
n=\frac{N \sum_{i=1}^{k} N_{i} s_{i}^{2}}{N^{2} V+\sum_{i=1}^{k} N_{i} s_{i}^{2}}
$$

\section{$\mathrm{d} \alpha / 2$ Precision}

\section{Z Reliability}

\section{N Population size}

\section{Ni Population size of stratum i}

\section{$\mathrm{S}^{2} \mathrm{i}$ Variance of stratum $\mathrm{i}$}

Equation 2. Relationship between precision and reliability for the calculation of the sample size in equation 1.

$$
V=\frac{d^{2}}{Z^{2}}
$$

Equation 3. Assignment of sample size to each of the strata.

$n_{\mathrm{i}}=\frac{N i}{N} n$

It was decided to use a precision of $15 \%$ of the general mean and a reliability of $90 \%$, therefore, with information obtained on the size of the strata and their variances, the following information is available:

$\begin{array}{lll}\begin{array}{l}\text { Population } \\ \text { Stratum 1 } \\ \text { population }\end{array} & \text { Region } & \mathrm{N}=892 \\ \begin{array}{l}\text { Stratum 2 } \\ \text { population }\end{array} & \text { Tzinacapan } & \mathrm{N} 2=305 \\ \text { Stratum 1 } & & \left(\mathrm{S}^{2}\right) 1= \\ \text { variance } & \text { Cuetzalan } & 1.518 \\ \text { Stratum 2 } & & \left(\mathrm{S}^{2}\right) 2= \\ \text { variance } & \text { Tzinacapan } & 0.841 \\ \text { Precision } & & \mathrm{d}=0.15 \\ \text { Reliability } & & \mathrm{z}=1.64\end{array}$

Substituting the data previously shown in equation $i$, we obtain the following data, the size of the sample in each of the municipalities, with a precision of $15 \%$ of the general mean and the reliability of $95 \%$, the size of the strata is of established as follows:

\begin{tabular}{|l|r|}
\hline Municipality & Sample size \\
\hline Cuetzalan & $\mathrm{n} 1=64$ \\
\hline Tzinacapan & $\mathrm{n} 2=37$ \\
\hline Total & $\mathrm{n}=101$ \\
\hline
\end{tabular}

Table 2 Sample size of the municipalities studied

Through a random procedure, 101 producers were interviewed 64 in Cuetzalan and 37 in Tzinacapan.

The sample design will be carried out in a stratified sampling, due to the divergence between the groups of producers in the Sierra Norte de Puebla. Information was sought on the coffee growers of this region and the list of problems was obtained through the coffee census, this census includes information to determine the sample size, the first thing that was done was to identify a variable that gives us information related to the Research topic and it was dedicated to use the number of farms as a necessary variable to determine the sample size in the first stage was to identify the number of farms, the number of producers, the number of farms and the area of coffee cultivation were used, analyzing variance.

XIMITL-ISLAS, Iván, RODRÍGUEZ-DE LA VEGA, Marisol, CABILDO-OREA, Alejandra and MACHORRO-DÍAZ, Rafael. Coffee production and marketing in the municipality of Cuetzalan del Progreso, Puebla, Mexico. RINOE Journal International Economy. 2020 


\section{Resultas}

\section{Life conditions}

The questionnaires applied in the study municipalities, in which 101 questionnaires were applied, 64 in the municipal capital and 37 in the town of San Miguel Tzinacapan, municipality of Cuetzalan del Progreso, representing 63\% and $37 \%$ respectively. Regarding the residence of the producers, $92.5 \%$ affirmed that it is originally from the locality, while $7.5 \%$ said that it is not. The information obtained shows that the number of inhabitants per dwelling represent the nuclear family, that is, less than 6 inhabitants per dwelling, the number of inhabitants is $2: 3.0 \%$, 4: $16.4 \%, 5: 25.4 \%, 6: 11.9 \%, 7: 14.9 \%, 8$ : $6.0 \%, 9: 4.5 \%, 10: 4.5 \%$ and $12: 3.0 \%$, so it follows that the extended family, even in rural populations, tends to be smaller due to what occurs in today the nuclear family.

The average number of inhabitants per dwelling for Cuetzalan is 6.22 , for Tzinacapan it is $5.17,(\mathrm{t}=1.967$; significance $=0.053)$, so there is no significant difference and the two municipalities have families of family size.

Given the conditions of poverty in which the families of the Northeast Sierra de Puebla live, the data indicate that $49.3 \%$ of the families interviewed have dirt floors, the second material, which is cement, represents $44.8 \%$, while refers to the mosaic and tile material is $4.5 \%$, and other materials $1.5 \%$.

The material of the wall with which the houses are built predominates stone with $47.8 \%$, because in the region it is a material that predominates in the properties, secondly, the partition or block is used, with $28.4 \%$, later the material is the sheet, either cardboard or metal with $19.4 \%$, adobe material and rods occupy $1.5 \%$ in their use.

The roofs of the houses, the main material is the sheet with $38.8 \%$, in second place concrete casting is used with $31.3 \%$ and the tile although it is traditionally used in regions with rains throughout the year, currently the high cost is inaccessible so it has been replaced by sheet roofs, occupying the third place with $29.9 \%$.
With regard to property, $74.6 \%$ responded that their house is their own, $13.4 \%$ is rented and $11.9 \%$ is loaned, so it is notable that homes are acquired through inheritance or sale of lots.

Due to the physical geographical conditions, water is an abundant resource in the northern sierra region of Puebla, so the fact of having the vital liquid corresponds to the degree of proximity with the municipal capitals and auxiliary boards, to obtain the resource through a service, that is to say through drinking water, this item represents $61.2 \%$, obtaining by well or water wheel is $19.4 \%$, the spring $16.4 \%$, the river $1.5 \%$ and another is runoff, also with the $1.5 \%$, so that only the homes that have drinking water are those close to the network.

\section{Employment and migration}

About twenty cases were found which mentioned that they emigrate temporarily at the end of the coffee and corn harvest, this migration is due to the need to obtain a better income to support their family and due to the lack of employment in their locality and the Low wages do not allow them to develop within their locality and that is why they resort to migration as a survival strategy, the reasons why they migrate are: $64.3 \%$ said it is for better alternatives, 14.3 for heritage, $17.9 \%$ for various reasons, whether due to marriage, business study, etc., and $3.6 \%$ for family problems.

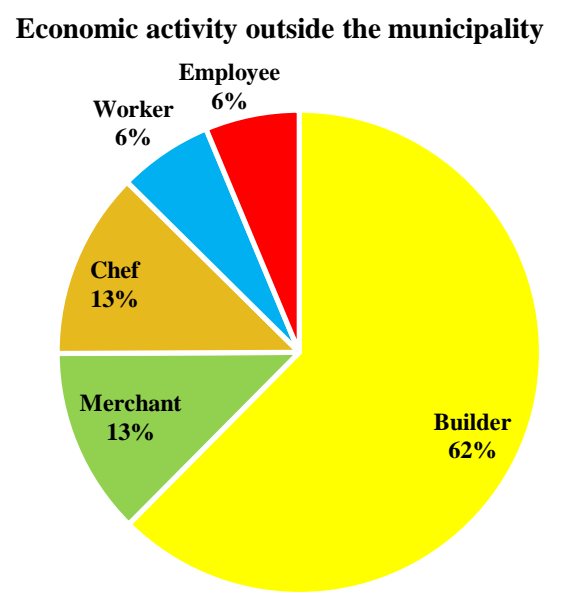

Figure 06

Source: Own elaboration with data collected in the field, March 2019

The main activity in which they are employed is in construction, so $62.5 \%$ are bricklayers, $12.5 \%$ are merchants, $12.5 \%$ work in the kitchen in restaurants, $6.3 \%$ are workers and $6.3 \%$ are employees.

XIMITL-ISLAS, Iván, RODRÍGUEZ-DE LA VEGA, Marisol, CABILDO-OREA, Alejandra and MACHORRO-DÍAZ, Rafael. Coffee production and marketing in the municipality of Cuetzalan del Progreso, Puebla, Mexico. RINOE Journal International Economy. 2020 
The main places where they reside are three: Puebla with $68.8 \%$, Mexico City with $18.8 \%$ and Veracruz with $12.5 \%$, which indicates that the city of Puebla is the main destination where they go looking for employment and Mexico City is the urban areas that absorb the labor force where salaries are $\$$ 100 per day, that is, three times those paid in the towns of srigen, as regards the state of Veracruz, it is due to the proximity of the northeastern highlands with the neighbor state.

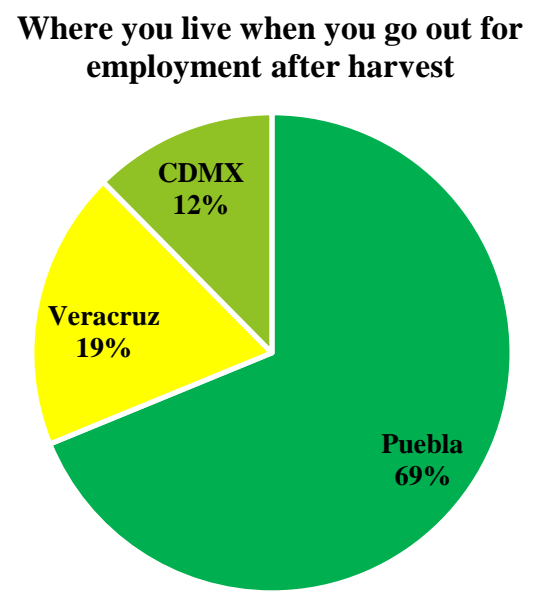

Figure 07

Source: Own elaboration with data collected in the field, March 2019

As previously mentioned, the migration effect to the present is still temporary, so it is during the corn and coffee harvest season when family work is most intense, although the social division of labor is fundamentally based on family work by What the producers pointed out that when it comes to the pinch of coffee and cultural tasks, the help of the children represents $40.3 \%$ that of the wife $34.3 \%$, and $25.4 \%$ hires day laborers.

\section{Agricultural production}

The information obtained shows that in the time series, coffee cultivation had a greater boom at the end of the eighties and the first half of the nineties, but in the second half of that decade it stopped growing significantly that there was an overproduction.

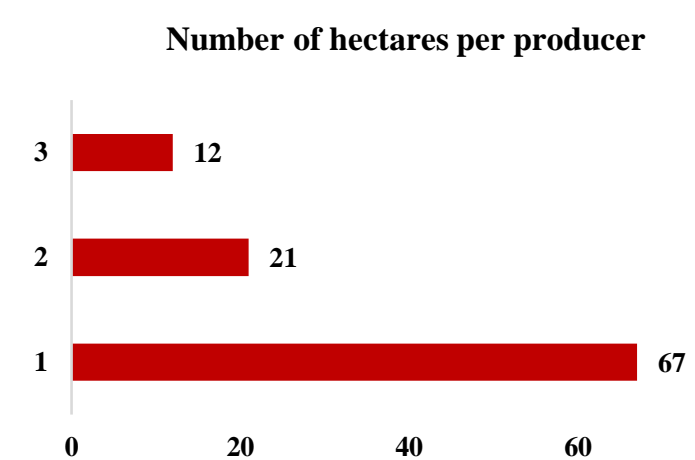

Figure 08

Source: Own elaboration with data collected in the field, March 2019

The cultivated area of coffee is smallholder, that is, it is less than 5 hectares in the production scale, so production is atomized and family gardens are highly relevant according to the 101 producers interviewed 67 mentioned that they have 1 hectare , 21 producers have 2 hectares and the rest have a ditch with more than 2.5 hectares, so the information of the sample indicates that most of the producers cultivate in 1 hectare of surface.

Another important fact is that coffee growers necessarily have a basic crop which is corn, where it is evident that there are two important crops, one that is commercial and the other that is for self-consumption, although 67 producers cultivate in 1 hectare, and 21 producers in 2, sometimes their production is not enough so the adversities of the weather, be it a drought or a frost, reduce the expected yield, so they go to community supply stores or street markets to stock up on basic grains such as They are miz and beans, on the other hand the other producers do not have land to grow corn, the reasons are because those who grow it and do not have land pay a rent of $\$ 1,700$ pesos per hectare or $\$ 1,400$ per bushel (half a hectare ) and prefer to buy the grains to invest in the crop.The average cultivated area of corn per producer, for Cuetzalan is $1.36 \mathrm{Ha}$., for Tzibacapan it is 1.22 , $\mathrm{t}=1.270$, the level of significance is 0.209 , so there is no significant difference.

The main variety used by coffee growers in the municipality of Cuetzalan is Mundo Novo with $47.8 \%$, then Caturra with $23.9 \%$, Catuai with $13.4 \%$, Garnica with $7.5 \%$, Bourbon with $4.5 \%$ and Timor hybrid with $3.0 \%$. Another species of great quality is the Creole. 


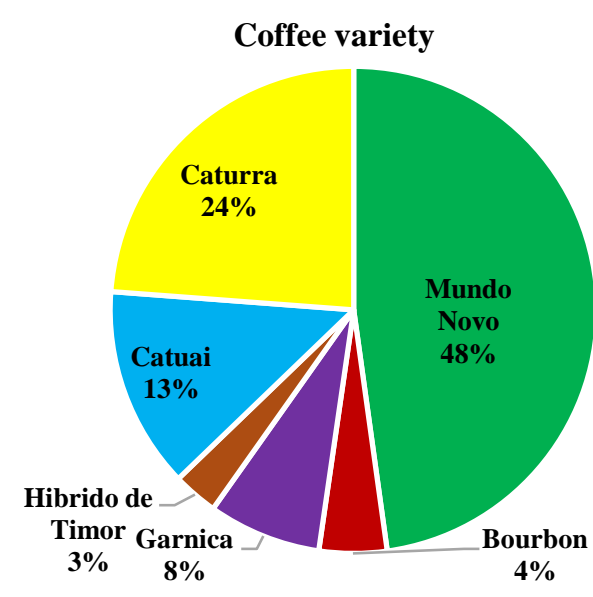

\section{Figure 09}

Source: Own elaboration with data collected in the field, March 2019

The population density of coffee plants is on the scale of 800 to 1200 plants per hectare according to the producers are those that are planted in one hectare, where replanting is necessary to preserve future productions, because coffee is a crop perennial that produces up to five years after being planted. The average number of coffee trees planted per hectare, for Cuetzalan is 1256.76, for Tzinacapan it is 1603.33, $(\mathrm{t}=2.438$, the level of significance is 0.018 , so there is a significant difference, where in Cuetzalan there is a higher density of planted coffee trees per property).

The activity of chapeo or cleaning (weeding) is necessary to have a better production and in turn have freedom at the time of harvest, in fact some government economic support is channeled for said activity, in order to improve production and productivity, Usually two chapeos are carried out per year, in which around five wages per hectare are used. $85.1 \%$ of the producers interviewed affirmed that they did chapeos, while $14.9 \%$ said that they did not.

The process after the cherry coffee harvest is washing and pulping, to obtain an almond which is put to dry to obtain parchment coffee, to be able to dry it in the houses of the producers, some dry it on the roofs, or in Cement patios for this process, those that do not have patios or cement ceilings dry it on mats or sacks, $64.2 \%$ indicated that they do have a drying patio, while $35.8 \%$ do not, so some producers in most of them sell their production in cherry coffee.

\section{Marketing of coffee}

The marketing channels that predominate in the study region are local, where the main places where Cuetzalan, Huehuetla, Zacapoaxtla, Xicotepec de Juárez and Jalapa Veracruz are found, intermediaries and organizations sell the grain to roasting companies, such as AMSA. To the agribusiness, the main presentation is the green coffee that is raw material to process, like parchment coffee, in the national market, on the other hand the sale to the international market, the main sale is organic coffee, La Sociedad Tosepan Titataniske is registered to export, so there are regulations to international standards.

With the information obtained in the field work, it was possible to describe the marketing channels that are presented in the study region in a schematic way, we can present it in the following Figure.

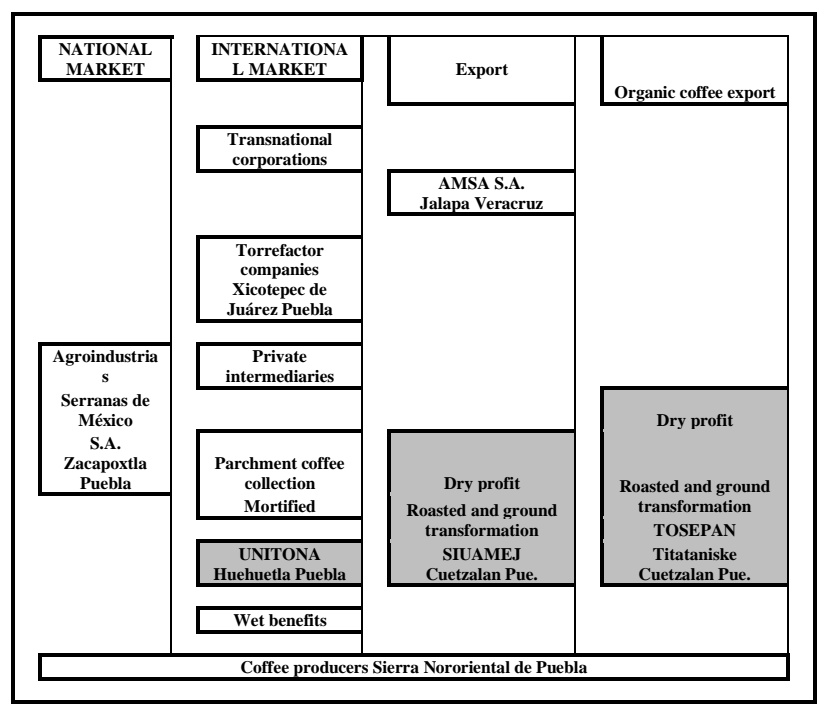

Figure 10 Local marketing channels of the study organizations, which are dedicated to the purchase and sale of coffee in the Sierra Nororiental de Puebla Source: self made

The central theme of this research is the role of organizations in the commercialization of coffee, which is why producers were questioned about their participation in an organization, only $23.9 \%$ answered that they belong to a producer organization, or a central peasant and $76.1 \%$ are not organized and work on their own account. 
Given the recent crisis in the price of coffee, producers prefer to sell their product in parchment coffee, because the price is higher than the price paid in cherry, in any case parchment requires more invested work, producers obtain it through family work and stores it in their homes, so that they obtain it as an opportunity cost, that is, when the price is established or is higher than expected, they go out to sell it on the days of the market, either with the organizations or with private intermediaries, due to fluctuations in both the external and local markets.

Regarding the income from the sale of coffee, the international price, when established on the rise, allows the income of the producers to have increased, which is why the sales of the producers range from $\$ 2,500$ to $\$ 6,000$ per average per hectare, the producers who obtain more than $\$ 6,500$ are those who have more than one hectare, the fact that the price has been reestablished does not mean that the living conditions of the producers have improved in the short term, the recent crisis that affected said Producers had made a change from coffee cultivation to basic ones, demolishing the coffee plantations and establishing pastures, the increase in the price of coffee is barely returning what was lost to the producers dedicated to this crop, since it should be noted that the income reported by the interviewed producers is per the total sale of your product is the result of arduous family work mainly where children, women, the elderly are employed without having a remu economic neration in a direct exploitation by capital which absorbs all that non-salaried labor force in obtaining the profit through the circulation of merchandise, the work invested is during the entire production process, since the harvest season is of November to March, so the income per family is the result of months of work in veneering, harvesting, washing, pulping and sale.

The average gross income from coffee sales for Cuetzalan was $\$ 6,659.56$, for Huehuetla it is $\$ 5,713.33, \mathrm{t}=-0.168$, the level of significance is 0.867 , so there is no significant difference.

The producers were asked in which they used the economic support, so that $70.4 \%$ for family expenses, that is, food and basic necessities, $17.9 \%$ used it to pay wages, $7.9 \%$ to buy inputs, and $3.2 \%$ for replanting.
The coffee growers were also asked according to which would be the way to improve the coffee cultivation activity, which was answered by 74 producers that with economic support, 12 producers regulating the price, 8 producers that the state would once again take charge of the commercialization of the coffee. coffee and finally 6 producers mentioned that through the organization reproducers to give added value to coffee and sell a product with a better price. Another problem that coffee growers face is the lack of technical assistance against $\mathrm{CBB}$ and Rust, which are pests that directly affect coffee trees and for this reason the coffee cannot meet the processing specifications with quality standards for its commercialization, the abandonment of coffee orchards and the lack of replanting and greenhouse management for the propagation of the coffee plant.

\section{Conclusions}

At present, the peasant organization continues to be in force, especially in indigenous communities because, being resistance societies, they continue to use forms of government that, although parallel to the laws established, allow them to develop autonomously, participation Politics is undoubtedly preponderant in the rural population, as it integrates through selfmanagement and the participation of the support received from government programs, which benefit the production of commercial and selfconsumption crops, as well as social assistance programs.

Faced with the recent crisis that the coffee sector has suffered, producers have sought to integrate into the coffee commercialization process, with the disappearance of INMECAFÉ, and remain in the free market, producers have sought a way to reduce intermediaries, give added value and looking for better markets where they can make their product, through an investment company. The price of coffee has recovered, but not necessarily this increase in the international price is reflected in the income of the producers, that is why the peasant organization adapts to the times, and seeks the benefit and development of the community, through the distribution of profits, according to the contributions of each partner and the degree of participation in the work of the various functions they perform throughout the production and marketing process.

XIMITL-ISLAS, Iván, RODRÍGUEZ-DE LA VEGA, Marisol, CABILDO-OREA, Alejandra and MACHORRO-DÍAZ, Rafael. Coffee production and marketing in the municipality of Cuetzalan del Progreso, Puebla, Mexico. RINOE Journal International Economy. 2020 
The contribution of benefits can not only be economic, such is the case of the indigenous unit in the peasant organization, which not only pursues monetary benefit, where two ethnic groups unite to preserve their uses and customs, in the indigenous language, traditional medicine, cultural workshops, an institution of upper secondary education, training for work as well as assistance in legal advice, in the indigenous court, where the administration of justice is taught in their mother tongue, these are some of the achievements that have been obtained through the joint struggle for better living conditions.

It is necessary to design agricultural policies that are based on peasant organization based on social relations of production based on a regional diagnosis, as well as technical assistance and training of coffee growers.

\section{References}

Alvarado-Méndez, (2006) Concepción; JuárezTlamani, Héctor; Ramírez-Valverde, Benito, La comercialización de café en una comunidad indígena: estudio en Huehuetla, Puebla, Ra Ximhai, vol. 2, núm. 2, mayo-agosto, pp. 293318, Universidad Autónoma Indígena de México. El Fuerte, Sinaloa, México.

Agoitia Juan Carlos (2002) "Café tendencias y perspectivas de exportaciones" BANCOMEXT, Centro de información estadística. México D.F.

ASERCA Apoyos y servicios a la
Comercialización Agropecuaria
"Situación del Café en México"
Revista
Realidades Agropecuarias; Número 103, Marzo
2002 Año XI. México D.F.

Becauge Pierre (1988) "La condición indígena en México”, en Revista de Sociología, Instituto de Investigaciones Sociológicas, Universidad Nacional Autónoma de México, I.I.S. U.N.A.M., México D.F.

Bonnis Gerard y Patron Sarti. (1997) "Politicas Nacionales y Políticas Agrícolas de México" Examen de las Politicas Agrícolas de México" Organización para la Cooperación y el Desarrollo Económicos, O.C.D.E. México D.F. Calva José Luis (1988) "Los campesinos y su devenir en las economías de mercado” Ed. Siglo XXI. México D.F.
Cerda, H. (1991). Medios, Instrumentos, técnicas y métodos de recopilación de datos e información. Los elementos de la investigación. Bogotá: El Búho. Colombia.

Durán Evelyne, Fernadez Ma. Teresa, Sinquin Evelyne. (1986) Rello Fernando Coordinador, En "Los productores rurales y sus problemas en el occidente de Méxco" Facultad de Economía. Universidad Nacional Autónoma de México, F.E. - U.N.A.M., Sistema de distribuidoras CONASUPO. México D.F.

D’Aubeterre-Buzneg, Eugenia; Rivermar-Pérez, Leticia, (2019) Movilidades y cadenas de valor en una localidad nahua de la Sierra Norte de Puebla, México, Íconos. Revista de Ciencias Sociales, núm. 63, Enero-Abril, pp. 55-73 FLACSO Ecuador.

Early K. Daniel (1979) “Café. Dependencia y efectos. Comunidades Nahuas de Zongolica Veracruz, en el mercado de Nueva York" Instituto Nacional Indigenista, I.N.I. México. D.F.

F.A.O. - SAGARPA (2004): "Informe de Evaluación Nacional Programa Fondo de Estabilización, Fortalecimiento y Reordenamiento de la Cafeticultura 2002/2003" octubre 2004. México D.F.

Gómez Aguilar Roberto (1979) "Introducción al muestreo" Tesis de Maestría en Ciencias en Estadística. Centro de Estadística y Cálculo. Colegio de Postgraduados. Chapingo México.

Hernández Loeza, Sergio Enrique; Vázquez Félix, Ángela María, (2015) Procesos organizativos y discursos confrontados en la defensa del territorio en la Sierra Norte de Puebla, Revista nuestrAmérica, vol. 3, núm. 5, enero-junio, pp. 75-91, Corriente nuestrAmérica desde Abajo, Concepción Chile.

Hernández Sampieri, Roberto, (2016). Fundamentos de Investigación, Mc Graw Hill, México.

Hernández Sampieri, Roberto, (2015). Metodología de la Investigación. Las Rutas Cuantitativa, Cualitativa Y Mixta Con Connect, Mc Graw Hill, México. 
Martínez Miguel Ángel, Evangelista Virginia, Basurto Francisco, Mendoza Myrna, Cruz-Rivas Antonio, (2007) Flora útil de los cafetales en la Sierra Norte de Puebla, México, Revista Mexicana de Biodiversidad 78: 15- 40, 2007.

Maxwell, Joseph A. (2019). Diseño De Investigación Cualitativa, Gedisa, México

Morales Carrillo Gudelio Antonio, Roberto García Mata, José Saturnino Mora Flores, José Alberto García Salazar, Eugenio Guzman Soria y Roberto Carlos García Sánchez (2005) En: "Tendencias recientes del precio del café verde, su impacto en México y en el mundo, 1958 2005." Comunicaciones en Socioeconomía, Estadística en Informática; Volumen 9 Número 2. Colegio de Postgraduados, Montecillo, Estado de México, México.

Ramírez Valverde Benito (2003) Proyecto "Estudio sobre estrategias para el Desarrollo Sustentable de la Sierra Nor-oriente de Puebla con la participación de productores, organizaciones e instituciones como respuesta a las condiciones de pobreza y marginación" Primer informe semestral. Fondo Mixto de Investigación Científica y Tecnológica CONACYT - Gobierno del Estado de Puebla. Puebla México.

Renard Maria Cristina. (1993) " $\mathrm{La}$ comercialización internacional del café" Colección Cuadernos Universitarios. Serie Ciencias Sociales, Número 11. Universidad Autónoma Chapingo U.A.Ch. Chapingo, Estado de México, México.

Ortega Hernández, Alejandro; Ramírez Valverde, Benito; Caso Barreda, Laura; Ramírez Juárez, Javier; Espinoza Sánchez, Gildardo; Morett Sánchez, Jesús, (2010) Transformación de la estructura agraria en un municipio indígena productor de café en un contexto de crisis. Estudio de caso en Huehuetla, Puebla, México, Región y Sociedad, vol. XXII, núm. 48, mayoagosto, pp. 145-178, El Colegio de Sonora, Hermosillo, México

Rivadeneyra Pasquel, José Ignacio; Ramírez Valverde, Benito, El comercio local del café a raíz de su crisis en la Sierra Norte de Puebla, Revista Mexicana de Agronegocios, vol. X, núm. 18, enero-junio, 2006, Sociedad Mexicana de Administración Agropecuaria A.C. Torreón, México.
Roberto Gómez Aguilar (1979) "Introducción al muestreo" Tesis de Maestría en Ciencias en Estadística. Centro de Estadística y Cálculo. Colegio de Postgraduados. Chapingo México

Rojas Soriano, Raúl, (2013) Guía para realizar investigaciones sociales, Plaza y Valdés, México.

Steffen Riedman Cristina y León López Arturo (1990) "Las cooperativas de la Sierra Norte de Puebla" En: Las Organizaciones de producción rural en México, Fernado Rello Compilador Facultad de Economía, Universidad Nacional Autónoma de México. F.E. - U.N.A.M. México D.F 